Article

\title{
Responses of Soil Microbial Community Composition and Enzyme Activities to Land-Use Change in the Eastern Tibetan Plateau, China
}

\author{
Da Luo ${ }^{1,2}$, Rui-Mei Cheng ${ }^{2,3}$, Shun Liu ${ }^{2}$, Zuo-Min Shi ${ }^{2,3,4, *}$ and Qiu-Hong Feng ${ }^{5}$ \\ 1 Institute of Economic Forests, Xinjiang Academy of Forestry Science, No.191 Anju South Road, \\ Urumqi 830063, China; luoda2010@163.com \\ 2 Key Laboratory of Forest Ecology and Environment of National Forestry and Grassland Administration, \\ Research Institute of Forest Ecology, Environment and Protection, Chinese Academy of \\ Forestry, No. 2 Dongxiaofu, Xiangshan Road, Haidian District, Beijing 100091, China; \\ chengrm@caf.ac.cn (R.-M.C.); liushun89@163.com (S.L.) \\ 3 Co-Innovation Center for Sustainable Forestry in Southern China, Nanjing Forestry University, \\ 159 Longpan Road, Nanjing 210037, China \\ 4 Institute for Sustainable Pant Protection, National Research Council of Italy, Strada delle Cacce 73, \\ 10135 Torino, Italy \\ 5 Ecological Restoration and Conservation on Forest and Wetland Key Laboratory of Sichuan Province, \\ Sichuan Academy of Forestry, No.18 Xinghui West Road, Chengdu 610081, China; fqiuhong@163.com \\ * Correspondence: shizm@caf.ac.cn; Tel.: +86-10-6288-8308; Fax: +86-10-6288-4972
}

Received: 15 March 2020; Accepted: 23 April 2020; Published: 25 April 2020

check for updates

\begin{abstract}
The land-use change is a major determinant influencing ecosystem carbon (C) patterns and nutrient cycling in subalpine forests in the Eastern Tibetan Plateau. While some results have been obtained in relation to the influence of land-use change on aboveground components, less is known about the belowground microbial communities and related processes. We assessed the structure and function of soil microbial communities following land-use change from old-growth forest (OF) to secondary forest (SF), plantation forest (PF), and grassland (GL) in the Eastern Tibetan Plateau, China. Phospholipid fatty acid profiles and enzyme activity analysis were used to determine the composition and activities of microbial communities, respectively. Significant differences in physicochemical characteristics, microbial communities, and extracellular enzyme activities in soils under different land uses were observed in this study. $\mathrm{pH}$ and total nitrogen (TN) in OF and SF were significantly higher than in GL. PF showed the highest soil organic C (SOC), and significantly higher than in GL. Total phosphorus (TP) and $\mathrm{C} / \mathrm{N}$ ratio in PF were significantly higher than the other land-use types. OF and PF had significantly higher anaerobic bacteria than in GL. The actinobacteria in SF was significantly higher than in PF. The saprotrophic and ectomycorrhizal (SEM) fungi was significantly lower in GL than the other land-use types. Total microbial biomass and $\beta$-glucosidase activities were significantly higher in OF and SF than in GL. GL had significantly higher polyphenoloxidase activities than in OF and PF. Anaerobic bacteria, arbuscular mycorrhizal fungi and SEM fungi were positively correlated with SOC and TP, Gram+ bacteria were correlated with C/P and N/P ratio. $\mathrm{N}$-acetylglucosaminidase activity was negatively correlated with anaerobic bacteria, while polyphenoloxidase activity was positively related to actinobacteria. Furthermore, redundancy analysis revealed that the microbial community composition was primarily regulated by TN and $\mathrm{pH}$. This suggested that altered land-use type initiated changes in the physicochemical characteristics of the soils, which affected the composition of microbial communities and microbial enzyme activities related to nutrient cycling in this area. This provides a scientific basis for the influence mechanism of land use on composition and function of microbial communities, as well as the rational utilization and management of land resources.
\end{abstract}


Keywords: microbial community composition; extracellular enzyme activity; phospholipid fatty acid; soil physicochemical properties; subalpine forest; land-use change

\section{Introduction}

Interactions between aboveground and belowground communities may strongly affect ecosystem functioning by regulating plant community dynamics and biogeochemical processes $[1,2]$. Belowground, soil microbial communities are treated as decomposers of organic materials, playing important roles in mediating carbon $(\mathrm{C})$ and nitrogen $(\mathrm{N})$ processes and nutrient availability that are critical for the growth and maintenance of plants [3,4]. Aboveground plant communities can substantially alter the composition, diversity, and functions of soil microbial communities by changing root system, rhizodeposition, litter chemistry, canopy structure, and subsequent influences on soil microclimate conditions and physicochemical properties $[5,6]$.

In human-influenced landscapes, land-use changes are accompanied by changes in aboveground plant communities and soil characteristics from which aboveground and belowground interactions develop [7]. It has been recognized that such land-use-driven change is a major determinant influencing soil microbial community [8,9]. Slight changes in microbial community structure and specific microbial functions, such as extracellular enzyme activities, have been considered to alter the processes of $C$ and $\mathrm{N}$ cycling [10]. Deeper understanding of the responses of soil microbial communities and processes in relation to land-use change therefore would greatly benefit land management and ecosystem restoration.

Recent studies, focused mainly on forest conversion or land-use change, have reported the impacts on the composition and activities of soil microbial communities [1,11-15]. Liu et al. [14], for example, investigated the influence of forest regeneration patterns on belowground microbial community composition and activities and found that soil enzyme activities significantly varied among forest types while bacterial and fungal community did not vary significantly. Ahmed et al. [11] showed that soil microbial properties and enzyme activities differed significantly among land-use types. Krashevska et al. [13] examined the effects of land-use change in terms of conversion from rainforests into rubber plantations and observed significant increase in the abundance of arbuscular mycorrhizal (AM) fungi and a decrease in bacterial abundance. Guo et al. [12] found significant changes in the relative abundance of anaerobic bacteria and AM fungi $(16: 1 \omega 5 c)$ due to conversion of native broadleaf forests to mixed plantations, or to bamboo forests. A recent study showed that both microbial biomass and enzymatic activity levels were distinctly lower in ancient oak forests when compared to historically cultivated sites [1]. In contrast, there have been no significant differences observed in microbial community composition or enzymatic activities in the "Montado ecosystem" [16] or between shrublands and broadleaf forests over 27 years of reforestation [17].

The subalpine forest ecosystems in the Eastern Tibetan Plateau located at the transition zone from the Qinghai-Tibetan plateau to the Sichuan Basin could be very sensitive to global climate change, with important consequences for biodiversity conservation and the global $\mathrm{C}$ and $\mathrm{N}$ balance. In the last century, the subalpine regions in southwestern China were largely covered by old-growth forest (OF) dominated by firs. With the widespread commercial logging and increased human activities during the second half of the 20th century, OF were deforested and replaced by natural secondary forest (SF), plantation forest (PF), or grassland (GL). Recently, forest restoration has been enhanced to improve forest cover in this region. Therefore, studies on belowground communities in response to land-use change can provide a good opportunity to improve the understanding of $C$ patterns and nutrient cycling in the subalpine forests. To date, studies on land-use change in this region have focused mainly on aboveground components, with less focus on soils and belowground community processes [18-21]. The size, structure, and function of microbial communities in soils may rapidly response to any changes in plant and soil characteristics because of different nutrient availability, substrate's quality and quantity, root exudates, and rhizodeposits [22-24]. 
This study aimed to assess potential effects of different land-use types (OF, SF, PF, GL) on (i) soil physicochemical characteristics and microbial community composition, and (ii) microbial extracellular enzyme activities. Furthermore, (iii) can we explain any variation in microbial community composition through the variations in soil physicochemical properties? We hypothesized that soil microbial community composition and extracellular enzyme activities would vary among land-use types. Specifically, we expected that differences in microbial community composition can be explained by differences in soil physicochemical properties induced by land use change.

\section{Materials and Methods}

\subsection{Study Site}

This study was conducted in the Miyaluo Experimental Forest Region $\left(31^{\circ} 24^{\prime}-31^{\circ} 55^{\prime} \mathrm{N}\right.$, $102^{\circ} 35^{\prime}-103^{\circ} 04^{\prime}$ E), located in Li County, Sichuan Province and in the Eastern Tibetan Plateau, China. This region has a typical subalpine climate (cold winter and cool summer), and altitude ranges from 2700-3600 $\mathrm{m}$ above sea level (a.s.1.). Mean air temperatures in January and July are $-8^{\circ} \mathrm{C}$ and $12.6^{\circ} \mathrm{C}$, respectively, and annual mean air temperature is $6.1^{\circ} \mathrm{C}$. Annual accumulated temperature $\left(\geq 10{ }^{\circ} \mathrm{C}\right)$ is $1200-1400{ }^{\circ} \mathrm{C}$. Annual mean rainfall is approximately $864 \mathrm{~mm}$, concentrated (about $70.0 \%$ ) between May and September, with an average potential evapotranspiration ranging between 1000 and $1900 \mathrm{~mm} \mathrm{y}^{-1}$. The soils at the study area are formed from weathered granite and classified as Cambisols according to Pedoclimatic Zones of China [25,26].

Historically, the primary subalpine forests predominantly contained firs (Abies faxoniana Rehd. et Wils) that were harvested from the 1940s until 1998 when the Natural Forest Protection Program started. The deforested lands were subsequently planted with spruce (Picea asperata Mast.) saplings without any fertilization applied. Spruce plantations had been established in some places of the harvested areas with sparse understory vegetation, and eventually formed monoculture forest ( . asperata plantation forest $(\mathrm{PF})$ ). Meanwhile, natural restoration was also carried out in areas without cultivation. Nevertheless, some of the deforested sites failed to form secondary forest (SF) and turned into grassland (GL). Thus, old-growth forest (OF), SF, PF, and GL now present on the subalpine area. Currently, OF is typically dominated by old growth $A$. faxoniana, SF is typically dominated by A. faxoniana and Betula albo-sinensis Burk., PF is P. asperata monoculture forest. The main understory species were Carex tristachya Thunb, Cystopteris montana (Lam.) Bernh ex Desv, Polygonum viviparum Linn, and Trisetum sibiricum Rupr, etc. The coverage of undergrowth vegetation was about $60 \%$ in OF and SF and $25 \%$ in PF. GL was mainly characterized as Lolium perenne L. and Thalictrum alpinum L., and the coverage was about 95\%.

\subsection{Experimental Design, Sampling and Processing}

In the studied site, four different land-use types (i.e., OF, SF, PF, and GL) were selected based on criteria of similar altitude and soil. The land-use types exhibited a mosaic distribution pattern. We chose three representative stands for each land-use type. The stands were hundreds of meters to kilometers apart. In each stand, one plot of $20 \mathrm{~m} \times 20 \mathrm{~m}$ was randomly established for sample collection and was approximately $200 \mathrm{~m}$ from the edge of the stand. Each plot served as the replicate, and consequently there were three replicates in each of the four land-use types. All the plots were on the southeastern slope.

To determine soil physicochemical properties, together with microbial community composition and microbial extracellular enzyme activities, in each plot, fallen litters were removed and soil samples $(0-10 \mathrm{~cm})$ were collected from five cores $(6 \mathrm{~cm}$ in diameter). The soil samples collected from each plot in the same period were thoroughly mixed to obtain one homogeneous and representative sample. After the composite samples were sieved $<2 \mathrm{~mm}$ to remove visible roots, stones, plant debris, and soil animals, all samples were placed in polyethylene bags in triplicate and immediately transported to the laboratory. One was air-dried and passed through a $0.25 \mathrm{~mm}$ sieve for soil physicochemical analysis, 
another was stored at $-20^{\circ} \mathrm{C}$ prior to phospholipid fatty acid (PLFA) profiles, and a third was used for microbial extracellular enzyme activity analysis.

\subsection{Soil Physicochemical Analysis}

Soil samples were air-dried (at room temperature), stored in air-tight plastic bags, and later analyzed for physicochemical properties. Soil $\mathrm{pH}$ was determined using a glass electrode meter in a 1:2.5 soil:deionized water solution. Soil organic carbon (SOC) was measured using the wet oxidation method with $\mathrm{K}_{2} \mathrm{Cr}_{2} \mathrm{O}_{7}$ and $\mathrm{H}_{2} \mathrm{SO}_{4}$, and $\mathrm{FeSO}_{4}$ titration. Total nitrogen (TN) content was measured using the Kjeldahl method. Total phosphorus (TP) was determined by inductively coupled plasma (ICP) mass spectrometry analysis (IRIS Intrepid II XSP, Thermo Electron Corporation, Boston, MA, USA). Briefly, one gram of soil samples was digested with $15 \mathrm{~mL}$ of $72 \%$ perchloric acid $\left(\mathrm{HClO}_{4}\right)$ at $203{ }^{\circ} \mathrm{C}$ until heavy fumes appeared and its contents turned to a white color like sand. After digestion the samples were filtered with filter paper, and $2 \mathrm{~mL}$ supernatant solution was neutralized with $4 \mathrm{~N}$ $\mathrm{NaOH}$ using p-nitrophenol as an indicator, and analyzed for TP [27]. Soil samples were extracted with $2 \mathrm{M}$ potassium chloride $(\mathrm{KCl})$ solution, and ammonium- $\mathrm{N}\left(\mathrm{NH}_{4}{ }^{+}-\mathrm{N}\right)$ and nitrate- $\mathrm{N}\left(\mathrm{NO}_{3}{ }^{-}-\mathrm{N}\right)$ in extracts were determined with a flow injection auto-analyzer (FIA, Lachat Instruments, Loveland, CO, USA). The $\mathrm{C} / \mathrm{N}$ ratio, $\mathrm{C} / \mathrm{P}$ ratio, and $\mathrm{N} / \mathrm{P}$ ratio were also calculated.

\subsection{PLFA Analysis}

PLFA analysis was used to determine microbial biomass and microbial community composition [28,29]. For the analysis of microbial lipids, fresh soil equivalent to $8 \mathrm{~g}$ dry weight were extracted with $23 \mathrm{~mL}$ of chloroform:methanol:phosphate buffer (1:2:0.8) for $2 \mathrm{~h}$. The chloroform layer was decanted and dried under $\mathrm{N}_{2}$ at $32{ }^{\circ} \mathrm{C}$. The extracts were sequentially fractionated into neutral lipids, glyceride, and phospholipids with chloroform, acetone, and methanol, respectively, using silica gel-filled solid-phase extraction cartridges. The samples were then subjected to mild alkaline methanolysis by dissolving them into $1 \mathrm{~mL}$ of methanol:toluene $(1: 1)$ and $1 \mathrm{~mL}$ of $0.2 \mathrm{~mol} \mathrm{~L}^{-1}$ potassium hydroxide $(\mathrm{KOH})$ solutions, at $37^{\circ} \mathrm{C}$ for $15 \mathrm{~min}$. Subsequently, $2 \mathrm{~mL}$ of water and $0.3 \mathrm{~mL}$ of $1.0 \mathrm{~mol} \mathrm{~L}^{-1}$ acetic acid were added. The resulting fatty acid methyl esters were separated, quantified, and identified by gas chromatography (GC, N6890, Agilent, Palo Alto, CA, USA) and fitted with a MIDI Sherlocks microbial identification system (Version 4.5, MIDI, Inc., Newark, DE, USA). Lipid peaks were determined manually using the associated Agilent FAME identification library, based on retention time, mass spectra, and comparison with standards. Peak areas were converted into nmol lipid $\mathrm{g}^{-1}$ dry soil based on the methyl nonadecanoate (19:0) internal standard concentrations.

The total nmol lipid $\mathrm{g}^{-1}$ dry soil (sum of all lipids present) was used as an index of total microbial biomass. In addition, chemically similar lipid indicators were used to represent ecological groups of microorganisms. These included the following: Gram-positive (Gram+) bacteria (sum of i14:0, i15:0,

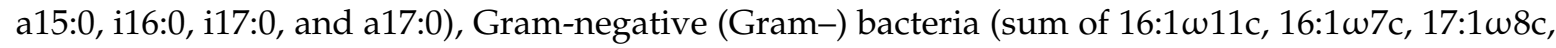

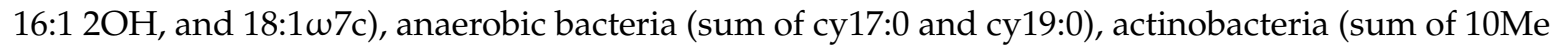
16:0, 10Me 17:0, 10Me 18:0, and 10Me 19:0), AM fungi (16:1 $\omega 5 \mathrm{c})$, and saprotrophic and ectomycorrhizal

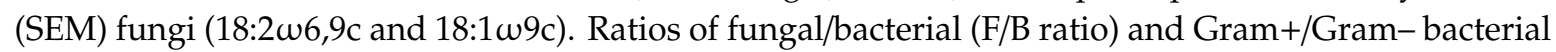
lipids (Gram+/Gram- ratio) were also included in the data analysis [1].

\subsection{Microbial Extracellular Enzyme Activity Analysis}

The function of the microbial communities in soils was assessed by analyzing the potential activities of three microbial extracellular enzymes. The activities of $\beta$-glucosidase and $\mathrm{N}$-acetylglucosaminidase were determined following the method of German et al. [30]. Briefly, soil sample suspensions were prepared by adding $4.0 \mathrm{~g}$ soil to $10 \mathrm{~mL}$ of $50 \mathrm{mM}$ sodium acetate buffer ( $\mathrm{pH}$ 5.0) and homogenizing for $0.5 \mathrm{~h}$ by oscillator. Then, $0.2 \mathrm{~mL}$ of $50 \mathrm{mM} p$-nitrophenyl $\beta$-D-glucopyranoside (for $\beta$-glucosidase assay) or $0.2 \mathrm{~mL}$ of $10 \mathrm{mM}$-nitrophenyl $\mathrm{N}$-acetyl- $\beta$-D-glucosaminide (for $\mathrm{N}$-acetylglucosaminidase assay) was added to $0.8 \mathrm{~mL}$ of prepared suspensions. The mixtures were incubated at $37^{\circ} \mathrm{C}$ in the 
dark for $1 \mathrm{~h}$. To stop the enzymatic reactions, $0.2 \mathrm{~mL}$ of $0.5 \mathrm{M}$ calcium chloride $\left(\mathrm{CaCl}_{2}\right)$ and $0.8 \mathrm{~mL}$ of 0.1 M Trishydroxymethylaminomethane-sodium hydroxide (THAM-NaOH, pH 12) buffer were added after incubation. In the control, the respective substrates were added before the addition of $\mathrm{CaCl}_{2}$ and THAM-NaOH. Polyphenoloxidase activity was determined according to Sinsabaugh et al. [31], using L-3,4-dihydroxyphenylalanine (L-DOPA) as substrate. All enzyme activities were expressed as nmol substrate $\mathrm{g}^{-1}$ dry soil $\mathrm{h}^{-1}$.

\subsection{Statistical Analysis}

To test if soil physicochemical properties $\left(\mathrm{pH}, \mathrm{SOC}, \mathrm{TN}, \mathrm{NH}_{4}{ }^{+}-\mathrm{N}, \mathrm{NO}_{3}{ }^{-}-\mathrm{N}, \mathrm{TP}, \mathrm{C} / \mathrm{N}\right.$ ratio, $\mathrm{C} / \mathrm{P}$ ratio, N/P ratio), microbial groups (total microbial biomass, Gram+ bacteria, Gram- bacteria, anaerobic bacteria, actinobacteria, AM fungi, SEM fungi, Gram+/Gram- ratio, F/B ratio), and microbial extracellular enzyme activities ( $\beta$-glucosidase, $\mathrm{N}$-acetylglucosaminidase, polyphenoloxidase) varied with land-use type, we conducted a series of one-way analysis of variance (ANOVA) followed by Tukey-HSD tests with land-use type as a fixed factor, and each attribute of soil physicochemical properties, microbial community groups, or microbial extracellular enzyme activities as responses. All data were checked for normality and homoscedasticity using Shapiro-Wilk and Bartlett's test, respectively. When these assumptions were not met, non-parametric Kruskal-Wallis tests were used. Additionally, Pearson's correlation coefficients were used to explore the relationship between the microbial groups and soil physicochemical properties, as well as microbial groups and enzyme activities. All statistical tests were performed using SPSS 19.0 (SPSS Inc., Chicago, IL, USA). Statistical significance was established at $p$ values $<0.05$. Microbial PLFA biomarkers obtained from the sampled soils were standardized before performing principal component analysis (PCA) to ensure each PLFA had the same weight in the analysis. Redundancy analysis (RDA) was used to analyze the responses of soil microbial community composition to physicochemical properties using CANOCO software (Version 4.5, Microcomputer Power, Inc., Ithaca, NY, USA) for Windows. Automatic selection of means by Monte Carlo permutations was used to test the significance of the variables ( $p$ values $<0.05)$. Figures were generated using SigmaPlot (Version 10.0, Systat Software, Inc., San Jose, CA, USA).

\section{Results}

\subsection{Soil Physicochemical Properties}

Soil physicochemical properties varied significantly according to land-use types (Table 1). Notably, $\mathrm{pH}$ and TN in OF and SF soils were significantly higher than in GL soil $(p<0.05)$. PF soil showed the highest SOC, and significantly higher than in GL soil $(p<0.05)$. The highest $\mathrm{NH}_{4}{ }^{+}-\mathrm{N}_{\text {was }}$ found in SF soil, while the lowest was observed in GL soil. GL soil had significantly higher $\mathrm{NO}_{3}{ }^{-}-\mathrm{N}$ than in $\mathrm{OF}$ and SF soils $(p<0.05)$. Additionally, TP and $\mathrm{C} / \mathrm{N}$ ratio in PF soil were significantly higher than the other land-use types $(p<0.05)$. C/P ratio and N/P ratio, however, were significantly lower in PF soil than the other land-use types $(p<0.05)$.

Table 1. Soil physicochemical properties of the upper $0-10 \mathrm{~cm}$ soil in different land-use types. Values are means \pm SE. Different letters indicate statistically significant differences among the land-use types (Tukey HSD test, 5\% level).

\begin{tabular}{ccccc}
\hline & Old-Growth Forest & Secondary Forest & Plantation Forest & Grassland \\
\hline $\mathrm{pH}$ & $5.98 \pm 0.18 \mathrm{a}$ & $5.82 \pm 0.03 \mathrm{a}$ & $5.34 \pm 0.05 \mathrm{ab}$ & $5.02 \pm 0.27 \mathrm{~b}$ \\
$\mathrm{SOC}\left(\mathrm{g} \mathrm{kg}^{-1}\right)$ & $61.79 \pm 3.97 \mathrm{a}$ & $52.32 \pm 2.42 \mathrm{ab}$ & $63.34 \pm 4.75 \mathrm{a}$ & $40.39 \pm 4.04 \mathrm{~b}$ \\
$\mathrm{TN}\left(\mathrm{g} \mathrm{kg}^{-1}\right)$ & $4.35 \pm 0.44 \mathrm{a}$ & $4.22 \pm 0.39 \mathrm{ab}$ & $3.24 \pm 0.12 \mathrm{bc}$ & $2.54 \pm 0.10 \mathrm{c}$ \\
$\mathrm{NH}_{4}^{+}-\mathrm{N}\left(\mathrm{mg} \mathrm{kg}^{-1}\right)$ & $10.99 \pm 2.03 \mathrm{ab}$ & $13.03 \pm 0.12 \mathrm{a}$ & $11.06 \pm 0.07 \mathrm{ab}$ & $8.61 \pm 1.47 \mathrm{~b}$ \\
$\mathrm{NO}_{3}{ }^{-}-\mathrm{N}\left(\mathrm{mg} \mathrm{kg}^{-1}\right)$ & $2.88 \pm 0.88 \mathrm{~b}$ & $3.17 \pm 1.21 \mathrm{~b}$ & $4.22 \pm 1.63 \mathrm{ab}$ & $8.38 \pm 1.84 \mathrm{a}$ \\
$\mathrm{TP}\left(\mathrm{mg} \mathrm{kg}^{-1}\right)$ & $76.07 \pm 4.65 \mathrm{~b}$ & $70.19 \pm 4.21 \mathrm{~b}$ & $116.31 \pm 3.21 \mathrm{a}$ & $43.46 \pm 5.23 \mathrm{c}$ \\
$\mathrm{C} / \mathrm{N} \mathrm{ratio}$ & $14.35 \pm 0.69 \mathrm{bc}$ & $12.52 \pm 0.64 \mathrm{c}$ & $19.50 \pm 0.97 \mathrm{a}$ & $15.82 \pm 1.08 \mathrm{~b}$ \\
$\mathrm{C} / \mathrm{P} \mathrm{ratio}$ & $812.24 \pm 17.61 \mathrm{ab}$ & $746.79 \pm 15.01 \mathrm{~b}$ & $547.63 \pm 57.06 \mathrm{c}$ & $938.16 \pm 68.36 \mathrm{a}$ \\
$\mathrm{N} / \mathrm{P}$ ratio & $56.96 \pm 3.77 \mathrm{a}$ & $59.89 \pm 2.36 \mathrm{a}$ & $27.96 \pm 1.64 \mathrm{~b}$ & $59.96 \pm 6.46 \mathrm{a}$ \\
\hline
\end{tabular}




\subsection{Soil Microbial Group PLFAs}

Land-use type significantly affected the relative abundance of anaerobic bacteria $(F=8.949$, $p<0.05)$, actinobacteria $(F=4.264, p<0.05)$, SEM fungi $(F=8.231, p<0.05)$, and $\mathrm{F} / \mathrm{B}$ ratio $(F=47.5$, $p<0.001)$. The relative abundance of anaerobic bacteria was significantly higher in $\mathrm{OF}(11.7 \%)$ and $\mathrm{PF}$ $(11.5 \%)$ soils than in GL $(9.9 \%)$ soil $(p<0.05)$ (Figure 1c). Actinobacterial abundance in SF soil was significantly higher than in PF soil $(p<0.05)$ (Figure 1d). SEM fungi was significantly lower in GL soil than the other land-use types $(p<0.05)$ (Figure $1 \mathrm{f})$. PF soil had significantly higher $\mathrm{F} / \mathrm{B}$ ratio than the other land-use types $(p<0.05)$ (Figure $1 \mathrm{~h})$. There was no significant difference among land-use types for the other microbial groups examined $(p>0.05$ ) (Figure 1a,b,e,g), except for Gram+ bacteria that were more abundant in GL soil than in PF soil (Figure 1a).
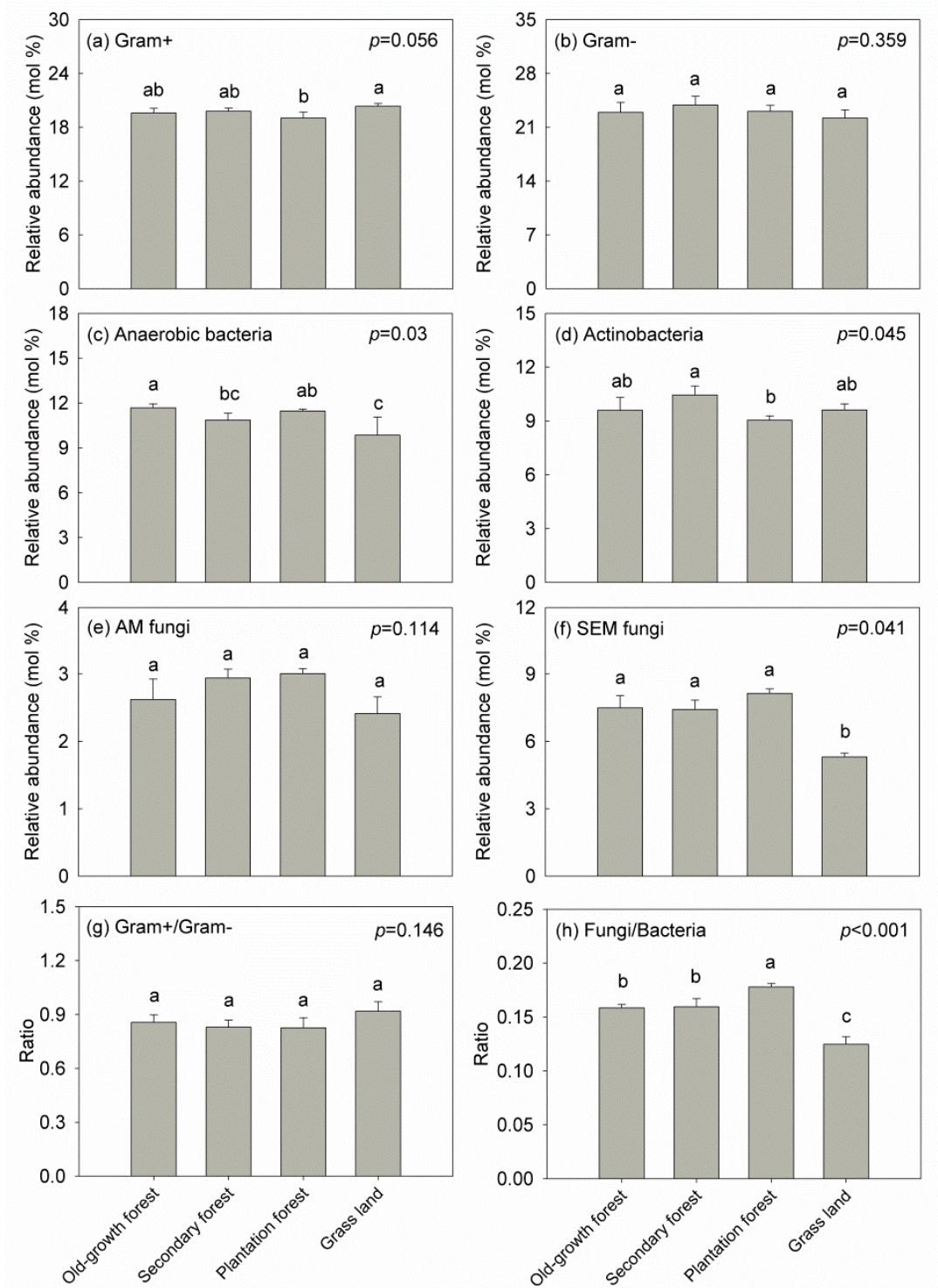

Figure 1. Relative abundance of different microbial group phospholipid fatty acids (PLFAs) in different land-use types. Error bars represent the standard error of the mean. Different letters indicate statistically significant differences among the land-use types (Tukey's HSD: $p<0.05$ ).

We found that SOC and TP were significantly and positively correlated with anaerobic bacteria, AM fungi, and SEM fungi. $\mathrm{NO}_{3}{ }^{-}-\mathrm{N}$ was negatively correlated with SEM fungi. TP, C/P ratio and 
$\mathrm{N} / \mathrm{P}$ ratio were correlated with Gram + bacteria. Additionally, C/P ratio appeared to be negatively correlated with anaerobic bacteria and SEM fungi (Table 2).

Table 2. Pearson's correlation coefficient $(R)$ testing association between microbial group phospholipid fatty acids (PLFAs) and soil physicochemical properties. $p$-values are shown in the parenthesis. Bold values indicate significant effects at $p<0.05$ or $p<0.01$.

\begin{tabular}{|c|c|c|c|c|c|c|}
\hline & Gram+ Bacteria & Gram-Bacteria & Anaerobic Bacteria & Actinobacteria & AM Fungi & SEM Fungi \\
\hline $\mathrm{pH}$ & $-0.14(0.67)$ & $0.39(0.21)$ & $0.49(0.11)$ & $0.32(0.31)$ & $0.25(0.43)$ & $0.44(0.16)$ \\
\hline SOC & $-0.41(0.19)$ & $0.18(0.57)$ & $0.60(0.04)$ & $-0.06(0.86)$ & $0.59(0.04)$ & $0.76(<0.01)$ \\
\hline $\mathrm{NH}_{4}{ }^{+}-\mathrm{N}$ & $-0.07(0.83)$ & $0.25(0.44)$ & $0.49(0.11)$ & $0.06(0.86)$ & $0.15(0.65)$ & $0.46(0.14)$ \\
\hline $\mathrm{NO}_{3}{ }^{-}-\mathrm{N}$ & $0.42(0.17)$ & $-0.25(0.43)$ & $-0.53(0.07)$ & $-0.12(0.72)$ & $-0.31(0.32)$ & $-0.68(0.02)$ \\
\hline $\mathrm{TP}$ & $-0.70(0.01)$ & $0.12(0.72)$ & $0.63(0.03)$ & $-0.38(0.22)$ & $0.65(0.02)$ & $0.81(<0.01)$ \\
\hline $\mathrm{N} / \mathrm{P}$ ratio & $0.63(0.03)$ & $0.03(0.92)$ & $-0.49(0.11)$ & $0.55(0.06)$ & $-0.40(0.20)$ & $-0.54(0.07)$ \\
\hline
\end{tabular}

SOC: soil organic carbon; TN: total nitrogen; TP: total phosphorus; $\mathrm{C} / \mathrm{N}$ : the ratio of soil organic carbon to total nitrogen; $\mathrm{C} / \mathrm{P}$ : the ratio of soil organic carbon to total phosphorus; $\mathrm{N} / \mathrm{P}$ : the ratio of total nitrogen to total phosphorus.

\subsection{Soil Microbial Community Composition}

The data concerning the individual relative abundance of the 24 most common PLFAs were subjected to a principal component analysis (PCA; Figure 2). Results showed that the first principal component (PC1) and the second principal component (PC2) together accounted for $66.7 \%$ of total variation of the soil microbial community composition. The PCA biplots revealed that the soil microbial community composition from OF was like that of SF. While the soil microbial communities from PF, GL, and SF were compositionally distinct from each other. GL with higher PC1 scores were observed on the right of the axes 1 . By their loading values, it is evident that the microbial PLFA biomarkers associated with gram-positive bacteria, including i14:0, i17:0, and a17:0, were all most important for the separation of the GL. The higher PC2 scores were observed for PF on the upper of the axes 2. Specifically, PF soil was abundant in AM fungal PLFA biomarkers (16:1w5c) and one of the SEM fungal PLFAs biomarkers (represented by 18:2w6,9c).
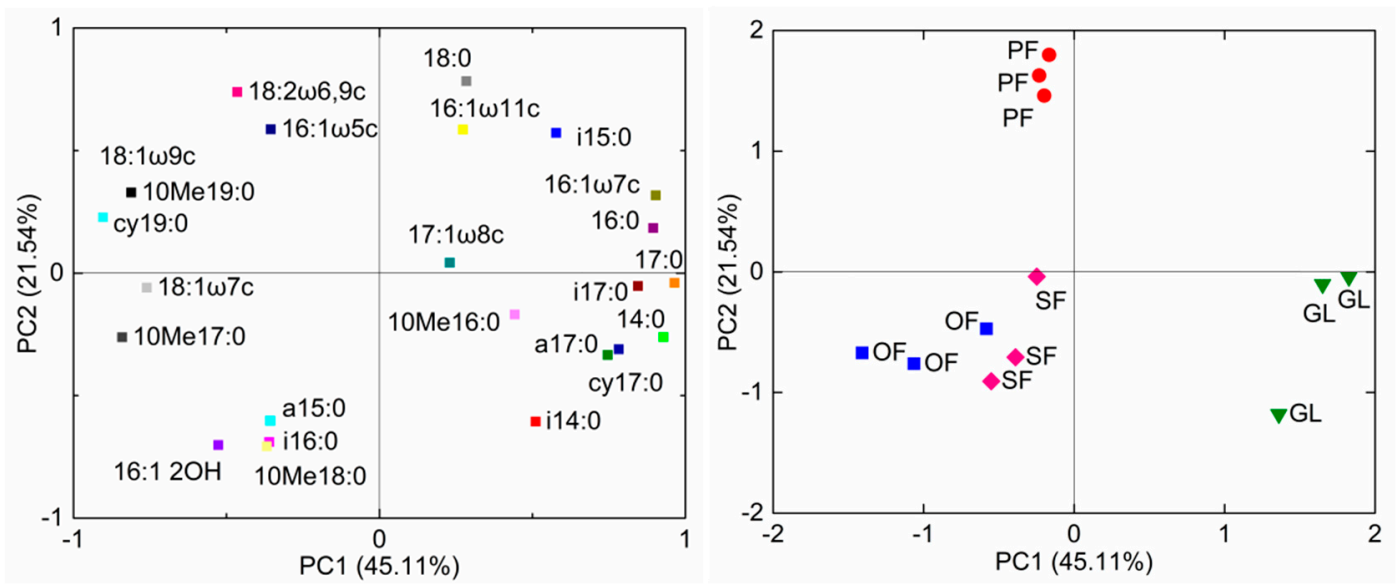

Figure 2. Principal component analysis (PCA) biplots of the phospholipid fatty acid (PLFA) (left) and microbial community composition in the soil samples from different land-use types (right). OF: old-growth forest; SF: secondary forest; PF: plantation forest; GL: grassland.

Redundancy analysis (RDA) of the relationships between soil microbial community composition and soil physicochemical properties showed that the first axes, RD1, explained $45.44 \%$ of the total variance in soil microbial communities, while the second axes (RD2) explained $21.74 \%$ of the total variance (Figure 3). 


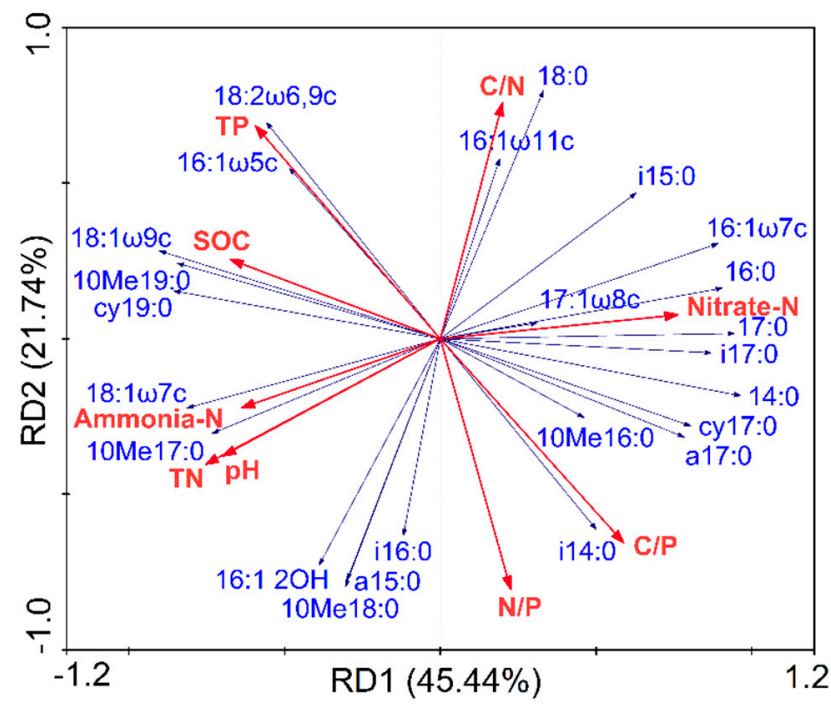

Figure 3. Redundancy analysis (RDA) of relationships between soil microbial community composition and physicochemical properties. The dashed lines with blue color represent the microbial phospholipid fatty acid (PLFA) biomarkers and the solid lines with red color represent the soil physicochemical variables. SOC: soil organic carbon; TN: total nitrogen; TP: total phosphorus; $\mathrm{C} / \mathrm{N}$ : the ratio of soil organic carbon to total nitrogen; $\mathrm{C} / \mathrm{P}$ : the ratio of soil organic carbon to total phosphorus; N/P: the ratio of total nitrogen to total phosphorus.

Nine variables-which included $\mathrm{pH}, \mathrm{SOC}, \mathrm{TN}, \mathrm{NH}_{4}{ }^{+}-\mathrm{N}, \mathrm{NO}_{3}{ }^{-}-\mathrm{N}, \mathrm{TP}, \mathrm{C} / \mathrm{N}$ ratio, $\mathrm{C} / \mathrm{P}$ ratio, and $\mathrm{N} / \mathrm{P}$ ratio-were found to be significantly correlated to soil microbial community composition (Table 3 ). These variables jointly explained $88 \%$ of the variations of the soil microbial community. The forward selection of the variables in the RDA showed that the soil microbial community composition across these four land-use types was primarily affected by the TN and $\mathrm{pH}$, which explained $30 \%$ and $23 \%$ of the variations, respectively.

Table 3. Marginal and conditional effects of forward selection through redundancy analysis (RDA).

\begin{tabular}{ccccc}
\hline Variables & Explained $\boldsymbol{\alpha}^{\mathbf{a}}$ & ${\text { Explained } \boldsymbol{\beta}^{\mathbf{b}}}^{\mathbf{c}}$ & $\boldsymbol{p}^{\mathbf{c}}$ & -Ratio $^{\mathbf{d}}$ \\
\hline $\mathrm{TN}$ & 0.30 & 0.30 & $\mathbf{0 . 0 0 8}$ & 4.25 \\
$\mathrm{pH}$ & 0.26 & 0.23 & $\mathbf{0 . 0 0 2}$ & 4.47 \\
TP & 0.27 & 0.07 & 0.194 & 1.43 \\
N/P & 0.18 & 0.07 & 0.190 & 1.52 \\
Ammonia-N & 0.21 & 0.05 & 0.436 & 1.02 \\
C/P & 0.26 & 0.04 & 0.452 & 0.89 \\
SOC & 0.24 & 0.06 & 0.382 & 1.16 \\
Nitrate-N & 0.27 & 0.03 & 0.556 & 0.73 \\
C/N & 0.17 & 0.03 & 0.656 & 0.50
\end{tabular}

\footnotetext{
a Marginal effects, which show the variance explained when the variable is used as the only factor. ${ }^{\mathrm{b}}$ Conditional effects, which show the additional variance each variable explains when it is include in the model. ${ }^{\mathrm{C}}$ Level of significance corresponding to $\mathrm{b}$ when performing Monte Carlo test at the 0.05 significance level. Bold values indicate significant effects at $p<0.05$. ${ }^{\mathrm{d}}$ Monte Carlo test statistics corresponding to $\mathrm{b}$ at the 0.05 significance level.
}

\subsection{Soil Microbial Biomass and Extracellular Enzyme Activities}

Land-use type had a marked impact on total microbial biomass $(F=23.717, p<0.001), \beta$-glucosidase $(F=6.347, p<0.05)$ and polyphenoloxidase activities $(F=11.565, p<0.01)$. Total microbial biomass, $\mathrm{N}$-acetylglucosaminidase and $\beta$-glucosidase activities were consistently higher in OF and SF soils than in GL soil (Figure $4 \mathrm{a}-\mathrm{c}$ ). However, differences in $\mathrm{N}$-acetylglucosaminidase activities were not 
statistically significant. Additionally, GL soil had significantly higher polyphenoloxidase activities than in OF and PF soils (Figure 4d).
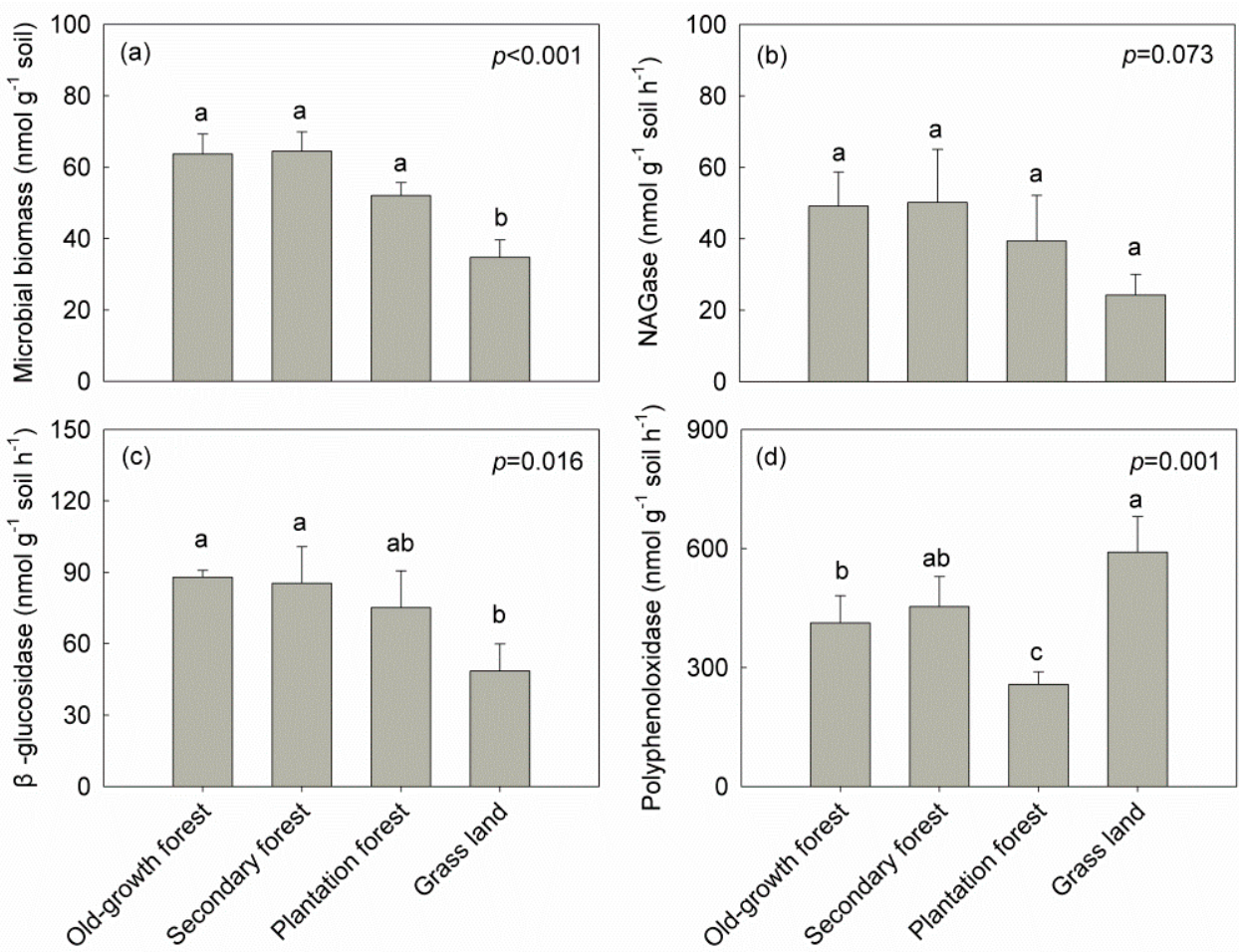

Figure 4. Soil total microbial biomass and microbial extracellular enzyme activities in different land-use types. Error bars represent the standard error of the mean. Different letters indicate statistically significant differences among the land-use types (Tukey HSD test, 5\% level). NAGase: N-acetylglucosaminidase.

In a correlation analysis, $\mathrm{N}$-acetylglucosaminidase and $\beta$-glucosidase activities significantly increased with increasing total microbial biomass. N-acetylglucosaminidase activity was negatively correlated with anaerobic bacteria, while polyphenoloxidase activity was positively related to actinobacteria. No other microbial variables showed any significant correlations with enzyme activities (Table 4).

Table 4. Pearson's correlation coefficient $(R)$ and $p$ values of regression between soil microbial group phospholipid fatty acids (PLFAs) and microbial extracellular enzyme activities.

\begin{tabular}{ccccccc}
\hline & \multicolumn{2}{c}{ N-acetylglucosaminidase } & \multicolumn{2}{c}{$\beta$-glucosidase } & \multicolumn{2}{c}{ Polyphenoloxidase } \\
\cline { 2 - 7 } & $\boldsymbol{R}$ & $\boldsymbol{p}$ & $\boldsymbol{R}$ & $\boldsymbol{p}$ & $\boldsymbol{R}$ & $\boldsymbol{p}$ \\
\hline Gram+ bacteria & 0.104 & 0.748 & 0.242 & 0.449 & 0.399 & 0.199 \\
Gram- bacteria & 0.439 & 0.153 & 0.183 & 0.570 & 0.205 & 0.523 \\
Anaerobic bacteria & -0.702 & $<0.05$ & -0.545 & 0.067 & 0.014 & 0.965 \\
Actinobacteria & 0.470 & 0.123 & 0.300 & 0.344 & 0.578 & $<0.05$ \\
AM fungi & 0.173 & 0.591 & 0.007 & 0.982 & -0.162 & 0.614 \\
SEM fungi & -0.340 & 0.280 & -0.346 & 0.271 & -0.131 & 0.685 \\
Gram+:Gram- ratio & -0.262 & 0.411 & -0.005 & 0.987 & 0.042 & 0.897 \\
Fungi:Bacteria ratio & -0.289 & 0.362 & -0.315 & 0.319 & -0.263 & 0.408 \\
Total microbial biomass & 0.624 & $<0.05$ & 0.718 & $<0.01$ & -0.443 & 0.149 \\
\hline
\end{tabular}




\section{Discussion}

The response of soil microbial community composition to land-use changes or disturbances is commonly assessed by community level PLFA profiles. For example, quite a few studies observed that soil microbial community showed some tree specificity [1,12]. Consistent with our hypothesis and findings from previous studies $[7,12,13]$, we found that land-use type had a significant influence on soil microbial communities and microbial extracellular enzyme activities (Figures 1 and 4), in large part, due to modified soil physicochemical properties and plant community structure. Contrarily, Bezemer et al. [32] and Lucas-Borja et al. [33] did not find any relationship between soil microbial community and land-use type.

Different microbial group PLFAs seemed to prefer different soil conditions [12,34-36]. Gram+ bacteria, for example, were positively correlated with increasing soil TP [12], while actinobacteria and $\mathrm{AM}$ fungi were strongly associated with $\mathrm{NH}_{4}{ }^{+}-\mathrm{N}$ and $\mathrm{NO}_{3}{ }^{-}-\mathrm{N}$ [23]. In the present study, due to the great afforestation density and fine-root biomass, meanwhile, because of the relatively gentle slope and less P loss of top soil, PF showed the highest values of SOC and TP (Table 1). We also found that anaerobic bacteria and SEM fungi were distinctly higher in OF and PF soils than in GL soil (Figure 1). Therefore, the anaerobic bacteria and SEM fungi seemed to prefer the soil conditions with higher SOC and TP concentrations, our further correlation analysis also confirmed this result (Table 2). A previous study in an oak forest showed that fertile soils favored highly microbial groups after land-use changes [1], which supported our findings. In addition, our observed trend toward lower Gram + bacteria in PF soil may be related to higher TP, lower C/P ratio or N/P ratio, since significant correlations were found between them (Table 2).

In the present study, RDA showed that the soil microbial community composition from OF soil was like that of SF soil (Figure 2), which consistent with previous findings that soil microbes under similar vegetation showed more similar community structure [33]. In addition, we found that microbial communities from OF (or SF), PF, and GL soils were compositionally distinct from each other (Figure 2), and the soil microbial community composition was mainly controlled by TN and pH (Figure 3 and Table 3). Previous studies also concluded that soil $\mathrm{N}$ availability could influence microbial growth in forest soils $[37,38]$. A recent study, for example, showed that bacteria generally have higher $\mathrm{N}$ demand (microbial $\mathrm{C} / \mathrm{N}=4$ for bacteria and 10 for fungi) [39] and therefore might develop well under $\mathrm{N}$-rich conditions. Soil $\mathrm{pH}$ is one of the major factors influencing the soil microbial community composition [40,41]. Nevertheless, it was also reported that there was no significant relationship between soil microbial community and $\mathrm{pH}$ [42]. Soil types and their associated soil characteristics, such as nutrient availability, texture, and soil moisture have varied in different studies, which might account for the inconsistent relationships.

Plant community structure and species identity has been shown to have significant influence on microbial communities in soils [43-45]. In this study, changes in plant communities associated with distinct land uses resulted in different microbial communities in soils (Figure 1). At least two aspects could be explained for this situation. First, different plant communities often select microorganisms differentially through affecting access to nutrients and plant rhizodeposits [22]. Second, the increase of plant community diversity can provide more types of food supply for belowground microbial communities, leading to more niche availability for soil microbes [1]. In this study, the plant community composition and structure were more complex in mixed forests (OF and SF) than that of monoculture PF and GL, meanwhile, mixed leaf litters that contained broad-leaved tree species (SF) often decompose at a faster rate than monoculture coniferous litters $(\mathrm{PF})$, such differences often affect the structure and activities of belowground microbial communities $[46,47]$.

Land-use-driven changes are likely to feedback on ecosystem $C$ and nutrient cycling through the effects on soil microbial communities [48]. Microorganisms produce extracellular enzymes in order to degrade complex organic substrates into monomers for nutrient acquisition [49,50]. Extracellular enzyme activities can, therefore, represent microbial nutrient limitation and decomposition potential in response to changes in soil quality or land-use change [1]. Soil enzymes can be divided into two broad 
groups: (i) hydrolytic enzymes (such as $\mathrm{N}$-acetylglucosaminidase and $\beta$-glucosidase) responsible for the acquisition of $\mathrm{C}, \mathrm{N}$, and $\mathrm{P}$ to support primary metabolism; and (ii) oxidative enzymes (such as polyphenoloxidase), produced primarily by fungi, which degrade poor-quality and chemically complex compounds like lignin in cometabolic acquisition of nutrients [31,51]. These groups of enzymes may respond differently to land-use change. In our study, land-use changes from OF to GL shifted enzyme production toward a decrease in $\beta$-glucosidase activities (Figure 4), which may reduce nutrient cycling rates and thus decrease nutrient acquisition for metabolism. However, such land-use changes decreased the SEM fungi abundance (Figure 1) but dramatically increased the production of polyphenoloxidase (Figure 4). Previous studies showed that, aside from soil microbes, soil properties ( $\mathrm{pH}$, bulk density, organic matter, TP, total potassium, etc.) and soil processes (soil respiration) were also the direct factors affecting soil enzyme activities [52]. Sinsabaugh et al. [31] found a strong relationship between soil $\mathrm{pH}$ and phenol oxidase when conducted a global-scale meta-analysis of soil enzyme activity. $\mathrm{Xu}$ et al. [52] observed that land-use changes from bare land to Casuarina equisetifolia L. plantation increased the fungi abundance, whereas it decreased the polyphenoloxidase, which is similar with our results. In addition, they concluded that soil texture and respiration were the key determinants influencing polyphenoloxidase activity. Therefore, it could be speculated that the soil properties may be the cause of the above results described in our study. Oxidative enzymes may contribute to humification and are typically linked to the depolymerization of recalcitrant organic compounds and poor-quality C compounds, such as aromatic C (found in lignin), as observed in Puerto Rico montane forests [53] and northern United States hardwood forests [54]. Environmental conditions that restrict in situ oxidative activities sustain an activity-limited feedback cycle that increases the $C$ storage [33]. These results indicate that there is likely to be significant variability in microbial community structural and functional responses to land-use change, with potential effects on soil $\mathrm{C}$ cycling.

\section{Conclusions}

In summary, we found strong evidence that land-use change has significant impacts on the structure and function of soil microbial communities in subalpine forests in the Eastern Tibetan Plateau. The microbial communities from OF (or SF), PF, and GL soils were compositionally distinct from each other. OF and PF had significantly higher anaerobic bacteria than in GL. The actinobacteria in SF was significantly higher than in PF. The SEM fungi was significantly lower in GL than the other land-use types. Total microbial biomass and $\beta$-glucosidase activities were significantly higher in OF and SF than in GL. GL had significantly higher polyphenoloxidase activities than in OF and PF. The microbial community composition was primarily regulated by soil physicochemical characteristics. These findings suggested that altered land-use type initiated changes in the physicochemical characteristics of the soils, which affected the composition of microbial communities and microbial enzyme activities related to nutrient cycling in this area. This provides a scientific basis for the influence mechanism of land use on composition and function of microbial communities, as well as the rational utilization and management of land resources.

Author Contributions: D.L. performed the experiments, analyzed the data, and wrote and revised the manuscript. R.-M.C. and S.L. performed the experiments and analyzed the data. Z.-M.S. conceived and designed the experiments, supervised the study and revised the paper. Q.-H.F. contributed to the experimental tools and conducted the field experiments. All authors contributed critically to the manuscript and gave final approval for publication. All authors have read and agreed to the published version of the manuscript.

Funding: This work was supported jointly by the National Key Research and Development Program (2016YFC0502104-02), the Fundamental Research Funds of CAF (CAFYBB2018ZA003), and the National Natural Science Foundation of China (31570240).

Acknowledgments: We are grateful to anonymous reviewers and the editors for their valuable comments and suggestions on the manuscript. We thank the staff in the Aba Autonomous Prefecture Forestry Institute of Science and Technology for their kind help with field investigations. A special thank goes to Shuxia Fu for PLFA extraction and Lixia Zhou for analysis and identification of PLFA extracts.

Conflicts of Interest: The authors declare that they have no conflict of interest. 


\section{References}

1. Fichtner, A.; Von Oheimb, G.; Härdtle, W.; Wilken, C.; Gutknecht, J. Effects of anthropogenic disturbances on soil microbial communities in oak forests persist for more than 100 years. Soil Biol. Biochem. 2014, $70,79-87$. [CrossRef]

2. Jin, Y.; Zhang, Y.; Xu, Z.; Gu, X.; Xu, J.; Tao, Y.; He, H.; Wang, A.; Liu, Y.; Niu, L. Soil microbial community and enzyme activity responses to herbaceous plant expansion in the Changbai Mountains tundra, China. Chin. Geogra. Sci. 2019, 29, 985-1000. [CrossRef]

3. Fanin, N.; Kardol, P.; Farrell, M.; Nilsson, M.C.; Gundale, M.J.; Wardle, D.A. The ratio of Gram-positive to Gram-negative bacterial PLFA markers as an indicator of carbon availability in organic soils. Soil Biol. Biochem. 2019, 128, 111-114. [CrossRef]

4. Ren, C.; Wang, T.; Xu, Y.; Deng, J.; Zhao, F.; Yang, G.; Han, X.; Feng, Y.; Ren, G. Differential soil microbial community responses to the linkage of soil organic carbon fractions with respiration across land-use changes. For. Ecol. Manag. 2018, 409, 170-178. [CrossRef]

5. Moscatelli, M.; Secondi, L.; Marabottini, R.; Papp, R.; Stazi, S.; Mania, E.; Marinari, S. Assessment of soil microbial functional diversity: Land use and soil properties affect CLPP-MicroResp and enzymes responses. Pedobiologia 2018, 66, 36-42. [CrossRef]

6. Prescott, C.E.; Grayston, S.J. Tree species influence on microbial communities in litter and soil: Current knowledge and research needs. For. Ecol. Manag. 2013, 309, 19-27. [CrossRef]

7. Lauber, C.L.; Strickland, M.S.; Bradford, M.A.; Fierer, N. The influence of soil properties on the structure of bacterial and fungal communities across land-use types. Soil Biol. Biochem. 2008, 40, 2407-2415. [CrossRef]

8. Bardgett, R.D.; Van Der Putten, W.H. Belowground biodiversity and ecosystem functioning. Nature 2014, 515, 505-511. [CrossRef]

9. Wu, S.J.; Deng, J.J.; Yin, Y.; Qin, S.J.; Zhu, W.X.; Zhou, Y.B.; Wang, B.; Ruan, H.H.; Jin, L. Bacterial community changes associated with land use type in the forest montane region of northeast China. Forests 2020, 11, 40. [CrossRef]

10. Ouyang, Y.; Reeve, J.R.; Norton, J.M. Soil enzyme activities and abundance of microbial functional genes involved in nitrogen transformations in an organic farming system. Biol. Fertil. Soils 2018, 54, 437-450. [CrossRef]

11. Ahmed, I.U.; Mengistie, H.K.; Godbold, D.L.; Sandén, H. Soil moisture integrates the influence of land-use and season on soil microbial community composition in the Ethiopian highlands. Appl. Soil Ecol. 2019, 135, 85-90. [CrossRef]

12. Guo, X.; Chen, H.Y.; Meng, M.; Biswas, S.R.; Ye, L.; Zhang, J. Effects of land use change on the composition of soil microbial communities in a managed subtropical forest. For. Ecol. Manag. 2016, 373, 93-99. [CrossRef]

13. Krashevska, V.; Klarner, B.; Widyastuti, R.; Maraun, M.; Scheu, S. Impact of tropical lowland rainforest conversion into rubber and oil palm plantations on soil microbial communities. Biol. Fertil. Soils 2015, 51, 697-705. [CrossRef]

14. Liu, S.; Luo, D.; Cheng, R.; Yang, H.; Wu, J.; Shi, Z. Soil-atmosphere exchange of greenhouse gases from typical subalpine forests on the eastern Qinghai-Tibetan Plateau: Effects of forest regeneration patterns. Land Degrad. Dev. 2020, 1-14. [CrossRef]

15. Yuan, Y.; Dai, X.; Xu, M.; Wang, H.; Fu, X.; Yang, F. Responses of microbial community structure to land-use conversion and fertilization in southern China. Eur. J. Soil Biol. 2015, 70, 1-6. [CrossRef]

16. Costa, D.; Freitas, H.; Sousa, J.P. Influence of seasons and land-use practices on soil microbial activity and metabolic diversity in the "Montado ecosystem". Eur. J. Soil Biol. 2013, 59, 22-30. [CrossRef]

17. Fu, X.; Yang, F.; Wang, J.; Di, Y.; Dai, X.; Zhang, X.; Wang, H. Understory vegetation leads to changes in soil acidity and in microbial communities 27 years after reforestation. Sci. Total Environ. 2015, 502, $280-286$. [CrossRef]

18. Liu, S.; Luo, D.; Yang, H.; Shi, Z.; Liu, Q.; Zhang, L.; Kang, Y. Fine root dynamics in three forest types with different origins in a subalpine region of the Eastern Qinghai-Tibetan Plateau. Forests 2018, 9, 517. [CrossRef]

19. Xu, Z.; Wan, C.; Xiong, P.; Tang, Z.; Hu, R.; Cao, G.; Liu, Q. Initial responses of soil $\mathrm{CO}_{2}$ efflux and C, N pools to experimental warming in two contrasting forest ecosystems, Eastern Tibetan Plateau, China. Plant Soil 2010, 336, 183-195. [CrossRef] 
20. Xu, G.; Chen, H.; Shi, Z.; Liu, S.; Cao, X.; Zhang, M.; Chen, M.; Chen, J.; Xiong, K.; Yang, H. Mycorrhizal and rhizospheric fungal community assembly differs during subalpine forest restoration on the eastern Qinghai-Tibetan Plateau. Plant Soil 2019, 1-15. [CrossRef]

21. Yin, H.; Chen, Z.; Liu, Q. Effects of experimental warming on soil $\mathrm{N}$ transformations of two coniferous species, Eastern Tibetan Plateau, China. Soil Biol. Biochem. 2012, 50, 77-84. [CrossRef]

22. Grayston, S.J.; Wang, S.; Campbell, C.D.; Edwards, A.C. Selective influence of plant species on microbial diversity in the rhizosphere. Soil Biol. Biochem. 1998, 30, 369-378. [CrossRef]

23. Luo, D.; Cheng, R.; Shi, Z.; Wang, W.; Xu, G.; Liu, S. Impacts of nitrogen-fixing and non-nitrogen-fixing tree species on soil respiration and microbial community composition during forest management in subtropical China. Ecol. Res. 2016, 31, 683-693. [CrossRef]

24. Zhang, X.; Dippold, M.A.; Kuzyakov, Y.; Razavi, B.S. Spatial pattern of enzyme activities depends on root exudate composition. Soil Biol. Biochem. 2019, 133, 83-93. [CrossRef]

25. IUSS Working Group WRB. World Reference Base for Soil Resources 2014, Update 2015 International Soil Classification System for Naming Soils and Creating Legends for Soil Maps; World Soil Resources Reports No. 106; FAO: Rome, Italy, 2015.

26. Tóth, G.; Song, X.; Hermann, T. Hierarchical and Multi-Scale Pedoclimatic Zonation Ref. Ares, 2017, 1485779-18/03/2017. Available online: https:/ec.europa.eu/research/participants/documents/downloadPublic? documentIds=080166e5b1171b67\&appId=PPGMS (accessed on 20 April 2020).

27. Gasparatos, D.; Haidouti, C. A comparison of wet oxidation methods for determination of total phosphorus in soils. J. Plant Nutr. Soil Sci. 2001, 164, 435-439. [CrossRef]

28. Frostegård, A.; Bååth, E. The use of phospholipid fatty acid analysis to estimate bacterial and fungal biomass in soil. Biol. Fertil. Soils 1996, 22, 59-65. [CrossRef]

29. Bossio, D.A.; Scow, K.M. Impacts of carbon and flooding on soil microbial communities: Phospholipid fatty acid profiles and substrate utilization patterns. Microb. Ecol. 1998, 35, 265-278. [CrossRef]

30. German, D.P.; Weintraub, M.N.; Grandy, A.S.; Lauber, C.L.; Rinkes, Z.L.; Allison, S.D. Optimization of hydrolytic and oxidative enzyme methods for ecosystem studies. Soil Biol. Biochem. 2011, 43, 1387-1397. [CrossRef]

31. Sinsabaugh, R.L.; Lauber, C.L.; Weintraub, M.N.; Ahmed, B.; Allison, S.D.; Crenshaw, C.; Contosta, A.R.; Cusack, D.; Frey, S.; Gallo, M.E. Stoichiometry of soil enzyme activity at global scale. Ecol. Lett. 2008, 11, 1252-1264. [CrossRef]

32. Bezemer, T.M.; Lawson, C.S.; Hedlund, K.; Edwards, A.R.; Brook, A.J.; Igual, J.M.; Mortimer, S.R.; Van Der Putten, W.H. Plant species and functional group effects on abiotic and microbial soil properties and plant-soil feedback responses in two grasslands. J. Ecol. 2006, 94, 893-904. [CrossRef]

33. Lucas-Borja, M.E.; Candel, D.; Jindo, K.; Moreno, J.; Andrés, M.; Bastida, F. Soil microbial community structure and activity in monospecific and mixed forest stands, under Mediterranean humid conditions. Plant Soil 2012, 354, 359-370. [CrossRef]

34. Richter, A.; Schöning, I.; Kahl, T.; Bauhus, J.; Ruess, L. Regional environmental conditions shape microbial community structure stronger than local forest management intensity. For. Ecol. Manag. 2018, 409, 250-259. [CrossRef]

35. Yang, N.; Ji, L.; Yang, Y.; Yang, L. The influence of tree species on soil properties and microbial communities following afforestation of abandoned land in northeast China. Eur. J. Soil Biol. 2018, 85, 73-78. [CrossRef]

36. Kang, H.; Gao, H.; Yu, W.; Yi, Y.; Wang, Y.; Ning, M. Changes in soil microbial community structure and function after afforestation depend on species and age: Case study in a subtropical alluvial island. Sci. Total Environ. 2018, 625, 1423-1432. [CrossRef]

37. Wagai, R.; Kitayama, K.; Satomura, T.; Fujinuma, R.; Balser, T. Interactive influences of climate and parent material on soil microbial community structure in Bornean tropical forest ecosystems. Ecol. Res. 2011, 26, 627-636. [CrossRef]

38. Xiao, D.; Che, R.; Liu, X.; Tan, Y.; Yang, R.; Zhang, W.; He, X.; Xu, Z.; Wang, K. Arbuscular mycorrhizal fungi abundance was sensitive to nitrogen addition but diversity was sensitive to phosphorus addition in karst ecosystems. Biol. Fertil. Soils 2019, 55, 457-469. [CrossRef]

39. Austin, A.T.; Yahdjian, L.; Stark, J.M.; Belnap, J.; Porporato, A.; Norton, U.; Ravetta, D.A.; Schaeffer, S.M. Water pulses and biogeochemical cycles in arid and semiarid ecosystems. Oecologia 2004, 141, 221-235. [CrossRef] 
40. Wu, X.; Xu, H.; Tuo, D.; Wang, C.; Fu, B.; Lv, Y.; Liu, G. Land use change and stand age regulate soil respiration by influencing soil substrate supply and microbial community. Geoderma 2020, 359, 113991. [CrossRef]

41. Yang, Y.; Cheng, H.; Liu, L.; Dou, Y.; An, S. Comparison of soil microbial community between planted woodland and natural grass vegetation on the Loess Plateau. For. Ecol. Manag. 2020, 460, 117817. [CrossRef]

42. Huang, X.; Liu, S.; Wang, H.; Hu, Z.; Li, Z.; You, Y. Changes of soil microbial biomass carbon and community composition through mixing nitrogen-fixing species with Eucalyptus urophylla in subtropical China. Soil Biol. Biochem. 2014, 73, 42-48. [CrossRef]

43. Angst, Š.; Harantová, L.; Baldrian, P.; Angst, G.; Cajthaml, T.; Straková, P.; Blahut, J.; Veselá, H.; Frouz, J. Tree species identity alters decomposition of understory litter and associated microbial communities: A case study. Biol. Fertil. Soils 2019, 55, 525-538. [CrossRef]

44. Dang, P.; Gao, Y.; Liu, J.; Yu, S.; Zhao, Z. Effects of thinning intensity on understory vegetation and soil microbial communities of a mature Chinese pine plantation in the Loess Plateau. Sci. Total Environ. 2018, 630, 171-180. [CrossRef] [PubMed]

45. Monkai, J.; Goldberg, S.D.; Hyde, K.D.; Harrison, R.D.; Mortimer, P.E.; Xu, J. Natural forests maintain a greater soil microbial diversity than that in rubber plantations in Southwest China. Agric. Ecosyst. Environ. 2018, 265, 190-197. [CrossRef]

46. Luo, D.; Cheng, R.; Shi, Z.; Wang, W. Decomposition of leaves and fine roots in three subtropical plantations in China affected by litter substrate quality and soil microbial community. Forests 2017, 8, 412. [CrossRef]

47. Osono, T. Decomposition of grass leaves by ligninolytic litter-decomposing fungi. Grassl. Sci. 2010, 56, 31-36. [CrossRef]

48. Shao, P.; Liang, C.; Lynch, L.; Xie, H.; Bao, X. Reforestation accelerates soil organic carbon accumulation: Evidence from microbial biomarkers. Soil Biol. Biochem. 2019, 131, 182-190. [CrossRef]

49. Feng, C.; Ma, Y.; Jin, X.; Wang, Z.; Ma, Y.; Fu, S.; Chen, H.Y. Soil enzyme activities increase following restoration of degraded subtropical forests. Geoderma 2019, 351, 180-187. [CrossRef]

50. LI, W.; Wu, M.; Liu, M.; Jiang, C.; Chen, X.; Kuzyakov, Y.; Rinklebe, J.; Li, Z. Responses of soil enzyme activities and microbial community composition to moisture regimes in paddy soils under long-term fertilization practices. Pedosphere 2018, 28, 323-331. [CrossRef]

51. Sinsabaugh, R.; Moorhead, D. Resource allocation to extracellular enzyme production: A model for nitrogen and phosphorus control of litter decomposition. Soil Biol. Biochem. 1994, 26, 1305-1311. [CrossRef]

52. Xu, Z.; Li, X.; Cai, L.; Li, Y.; Liu, S.; Liu, W.; Li, L. Analysis of soil microbial community and enzyme activity of Casuarina equisetifolia plantations at different stand ages in Hainan. J. Northwest A F Univ. (Nat. Sci. Ed.) 2018, 46, 24-34.

53. Cusack, D.F.; Silver, W.L.; Torn, M.S.; Burton, S.D.; Firestone, M.K. Changes in microbial community characteristics and soil organic matter with nitrogen additions in two tropical forests. Ecology 2011, 92, 621-632. [CrossRef] [PubMed]

54. Gallo, M.; Lauber, C.; Cabaniss, S.; Waldrop, M.; Sinsabaugh, R.; Zak, D.R. Soil organic matter and litter chemistry response to experimental $\mathrm{N}$ deposition in northern temperate deciduous forest ecosystems. Glob. Chang. Biol. 2005, 11, 1514-1521. [CrossRef]

(C) 2020 by the authors. Licensee MDPI, Basel, Switzerland. This article is an open access article distributed under the terms and conditions of the Creative Commons Attribution (CC BY) license (http://creativecommons.org/licenses/by/4.0/). 